Virginia Commonwealth University vCU Scholars Compass

1983

\title{
Comparison of Intermediate-Dose Methotrexate with Cranial Irradiation for the Post-Induction Treatment of Acute Lymphocytic Leukemia in Children
}

Arnold I. Freeman, M.D.

University of Toronto

Vivian Weinberg

UCSF Helen Diller Family Comprehensive Cancer Center

Martin L. Brecher, M.D.

State University of New York at Buffalo

See next page for additional authors

Follow this and additional works at: http://scholarscompass.vcu.edu/pediatrics_pubs

Part of the Pediatrics Commons

From The New England Journal of Medicine, Freeman, A.I., Weinberg, V., Brecher, M.L., et al., Comparison of Intermediate-Dose Methotrexate with Cranial Irradiation for the Post-Induction Treatment of Acute Lymphocytic Leukemia in Children, Vol. 308, Page 477, Copyright (C) 1983 Massachusetts Medical Society. Reprinted with permission.

\section{Downloaded from}

http://scholarscompass.vcu.edu/pediatrics_pubs/19

This Article is brought to you for free and open access by the Dept. of Pediatrics at VCU Scholars Compass. It has been accepted for inclusion in Pediatrics Publications by an authorized administrator of VCU Scholars Compass. For more information, please contact libcompass@vcu.edu. 


\section{Authors}

Arnold I. Freeman , M.D.; Vivian Weinberg; Martin L. Brecher , M.D.; Barbara Jones , M.D.; Arvin S. Glicksman , M.D.; Lucius F. Sinks , M.D.; Marise Weil , M.D.; Hansjuerg Pleuss , M.D.; Juliet Hananian , M.D.; E. Omer Burgert , Jr., M.D.; Gerald S. Gilchrist , M.D.; Thomas Necheles , M.D.; Michael Harris , M.D.; Faith Kung, M.D.; Richard B. Patterson , M.D.; Harold Maurer , M.D.; Brigid Leventhal , M.D.; Louise Chevalier, M.D.; Edwin Forman , M.D.; and James F. Holland, M.D. 


\title{
COMPARISON OF INTERMEDIATE-DOSE METHOTREXATE WITH CRANIAL IRRADIATION FOR THE POST-INDUCTION TREATMENT OF ACUTE LYMPHOCYTIC LEUKEMIA IN CHILDREN
}

\author{
Arnold I. Freeman, M.D., Vivian Weinberg, Martin L. Brecher, M.D., Barbara Jones, M.D., \\ Arvin S. Glicksman, M.D., Lucius F. Sinks, M.D., Marise Weil, M.D., Hansjuerg Pleuss, M.D., \\ Juliet Hananian, M.D., E. Omer Burgert, Jr., M.D., Gerald S. Gilchrist, M.D., \\ Thomas Necheles, M.D., Michaei. Harris, M.D., Fatth Kung, M.D., Richard B. Patterson, M.D., \\ Harold Maurer, M.D., Brigid Leventhal, M.D., Louise Chevalier, M.D., \\ Edwin Forman, M.D., and James F. Holland, M.D.
}

\begin{abstract}
We compared two regimens with respect to their ability to prolong disease-free survival in 506 children and adolescents with acute lymphocytic leukemia. All responders to induction therapy were randomized to treatment with 2400 rad of cranial irradiation plus intrathecal methotrexate or to treatment with intermediate-dose methotrexate plus intrathecal methotrexate, as prophylaxis for involvement of the central nervous system and other "sanctuary" areas. Patients were then treated with a standard maintenance regimen. Complete responders were stratified into either standard-risk or increased-risk groups on the basis of age and white-cell count at presentation.
\end{abstract}

Among patients with standard risk, hematologic relapses occurred in 9 of 117 given methotrexate and 24 of

$\mathrm{T}$ HE survival of children with acute lymphocytic lcukemia (ALL) has improved dramatically in the past 15 years, so that over half may be curcd. This improvement has been due to the use of central-nervous-system "prophylaxis" as well as effective systemic chemotherapy.

Without central-nervous-system "prophylaxis," central-nervous-system lcukemia devclops in approximately half these children.' Classical teaching has held that once central-nervous-system leukemia occurs, very few are cured. This concept has recently been challenged by Nesbit et al. ${ }^{2}$; in fact, these investigators noted that isolated central-ncrvous-system rclapse did not have a negative impact on survival. This analysis may be overly optimistic: although a substantial proportion of children with an isolated central-nervoussystem relapse may be saved, an appreciable percentage will cventually dic of leukemia. ${ }^{3}$

In 1968 Cancer and Lcukcmia Group B (CALGB) demonstrated that the use of prophylactic intrathecal methotrexate alone decreased the incidence of overt

From the Department of Pediatrics, Roswell Park Memorial Institute, Buffalo, N.Y.; Cancer and Leukemia Group B Operations Office, Scarsdale, N.Y.: the Department of Pediatrics, West Virginia University Medical Center. Morgantown: the Department of Radiation Oncology and the Department of Pediatrics, Rhode Island Hospital, Providence; the Department of Pediatrics, Institute de Recherches sur les Leucemies, Paris; the Division of Oncology. Swiss Coxperalive Group. Zurich; the Department of Pediatrics, University of Miami Medical Center, Miami; the Department of Pediatrics, Mayo Clinic, Rochester, Minn.: the Department of Pediatrics, New England Medical Center, Boston; the Department of Pediatrics and the Department of Neoplastic Diseases. Mount Sinai Hospital, New York; the Department of Pediatrics, University of California Medical Center, San Diego; the Department of Pediatrics. Bowman Gray School of Medicine. Winston-Silem, N.C.; the Department of Pediatrics, Medical College of Virginia, Richmond; and the Department of Pediatrics. Montreal Children's Hospital, Montreal. Address reprint requests to Dr. Freeman at the Department of Pediatrics, Roswell Park Memorial Institute, 666 Elm St., Buffalo, NY 14263.
120 given irradiation $(P<0.01)$. The rate of central-nervous-system relapse was higher in the methotrexate group (23 of 117) than in the irradiation group (8 of 120) $(P=0.01)$. Among patients with increased risk, radiation offered greater protection to the central nervous system than methotrexate $(P=0.03)$; there was no difference in the rate of hematologic relapse. In both risk strata the frequency of testicular relapse was significantly lower in the methotrexate group (1 patient) than the radiation group (10 patients) $(P=0.01)$.

Methotrexate offered better protection against systemic relapse in standard-risk patients and better protection against testicular relapse overall, but it offered less protection against relapses in the central nervous system than cranial irradiation. (N Engl J Med. 1983; 308:477-84.)

central-ncrvous-system leukemia from over 50 per cent to 23 per cent. ${ }^{4}$ The addition of cranial irradiation to intrathecal methotrexate as central-ncrvoussystem prophylaxis further reduced the incidence of central-ncrvous-system discase to approximately 10 per cent. ${ }^{5-9}$

However, cranial irradiation clcarly cannot cradicatc leukemic cells in regions other than the cranial cavity - c.g., the gonads, liver, and spleen. In particular, the problem of late testicular relapses has been emphasized by two coopcrative group studics. ${ }^{10,11}$ Furthermore, intellectual impairment after prophylactic cranial irradiation has becn a growing concern, leading us to explore alternative forms of central-ncrvous-system prophylaxis. ${ }^{12}$ In 1973 we began a pilot study at the Roswell Park Memorial Institute, with the following objectives: to prevent the development of central-nervous-system leukemia without using cranial irradiation, and to intensify systemic therapy and thus cradicate lcukemic cells in other "sanctuary" arcas. This study was based on clinical pharmacologic data demonstrating that intravenous intermediate-dose methotrexatc in a dose of $500 \mathrm{mg}$ per square meter of body-surface area, given over 24 hours, was capable of diffusing across the centralnervous-system barrier in amounts adequate to cradicatc lcukemic cells in the central nervous system ${ }^{13}$ and, presumably, to penctrate other regions simultancously. The preliminary results of the pilot study were encouraging and led to a definitive randomized study (CALGB Protocol 7611), in which "standard therapy" with cranial irradiation (2400 rad) plus intrathecal methotrexate was compared with intermediate-dose methotrexatc plus intrathecal methotrexate, with re- 
spect to their ability to improve disease-frec survival by reducing systemic, central-nervous-system, and cxtramedullary relapses. This paper reports the results of this study after a median follow-up period of 40 months.

\section{MeThods}

\section{Patient Ellgibility and Selection}

Previously untreated patients with ALI, who were less than 20 years old, including those with undifferentiated or stem-cell Al.L, were eligible for entry after informed consent had been obtained. Patients with hyperuricemia, active infections, or evidence of severe renal or hepatic dysfunction were excluded from entry until these abnormalities had been brought under control.

The French-American-British classification was not used, and cell-surface markers were not a prerequisite since many of the participating centers did not have the capacity to investigate them when the study was begun.

Spinal taps were performed routinely during the induction and intensification phase but not thercafter unless there was clinical evidence of central-nervous-system relapse. After remaining in continuous complete remission for three years and before completing therapy, all patients underwent a diagnostic spinal tap.

Bone-marrow aspirates were examined before the beginning of induction therapy, at Day 28 and Day 42 (before prophylactic therapy), and every three months thercafter or at any time that relapse was suspected. The criteria for determining complete remission have been described previously. ${ }^{14}$ Remission was indicated by bone marrow with normal granulopoicsis, thrombopoicsis, and crythropoiesis with less than 5 per cent lymphoblasts or less than a 40 per cent total of lymphocytes and lymphoblasts. The patient's performance status, physical findings, and peripheral-blood chemistry had to have reverted to normal. Induction therapy was considered a failure if the bone marrow did not indicate a remission by Day 42 .

I.cukoencephalopathy was defined clinically as the persistent unexplained presence of confusion, somnolence, ataxia, spasticity, focal neurologic changes, and scizures, in association with C'T scans showing calcification, hypodense white matter, dilatation of the ventricles, and an increase in the size of the cortical sulci. ${ }^{15}$ If a pathological examination was carried out, discrete necrotic foci and reactive astrocytosis ${ }^{16,17}$ were required for histologic confirmation.

For purposes of analysis, relapse or the termination of complete remission was defined as one of the following: (1) bone-marrow relapse (more than 25 per cent blast cells); (2) central-nervoussystem relapse (definite blast cells on cytologic [cytocentrifuge] preparations of cerebrospinal fluid, or 10 mononuclear cells per microliter whose presence was not attributable to chemical meningitis); (3) biopsy-confirmed leukemic relapse in an extramedullary organ; or (4) death during complete remission. If a patient had a relapse of any type, the treatment was considered to have failed and the patient was withdrawn from the study.

\section{Statistical Analysis}

Curves for remission duration were drawn according to the actuarial life-table technique to calculate the percentage of patients in remission. ${ }^{18}$ Differences in patterns of relapse were determined with Breslow's modification of the Kruskal-Wallis test. ${ }^{19}$ Differences between treatments in distributions of the features of patients were examined with the chi-square test for contingency tables. ${ }^{20}$ Multivariate regression analyses using Cox's regression model for concomitant variables were performed to identify features prognostic of remission duration. ${ }^{21}$

\section{Treatment Assignment}

A registration card for each patient was submitted to the CALGB Statistical Office before the start of protocol therapy. 'The initial therapy was identical for all patients entered. After completing induction therapy, complete responders were randomized to prophylactic therapy - either intermediate-dose methotrexate plus intrathecal methotrexate, or cranial irradiation plus intrathecal methotrexate - by means of sealed envelopes; treatment assignment was determined by a latin-square arrangement that balanced assignment within and across institutions. Patients were stratified according to type of risk, according to CALGB criteria that combined values for age and white-cell count at presentation; a patient was considered to be at standard risk if the initial white-cell count was less than 30,000 and if the age was more than two but less than eight years. All other patients werc classified as being at increased risk. Patients were randomized from within each risk stratum.

\section{Treatment (Fig. 1)}

\section{Induction Phase}

All patients received the same induction therapy: intravenous vincristine, $2 \mathrm{mg}$ per square meter per weck, for four doses (with a maximum single dose of $2 \mathrm{mg}$ ); oral prednisone, $40 \mathrm{mg}$ per square meter per day, given for four weeks and then tapered over approximately 10 days; intrathecal methotrexate, $12 \mathrm{mg}$ per square meter for three doses (with a maximum single dose of $15 \mathrm{mg}$ ); and intravenous asparaginase, $1000 \mathrm{IU}$ per kilogram of body weight per day, for 10 doses. If after four weeks the bone marrow was M-2 (5 to 25 per cent blast cells) or M-3 (>25 per cent blast cells), vincristine and prednisone induction was continued for two additional weeks, to be followed by asparaginase. If at the end of six weeks $M-1$ ( $<5$ per cent blast cells) marrow was not present, induction was considered to have failed and the patient was withdrawn. Upon complete remission and after 10 days of asparaginase therapy, a paticnt was randomized to receive either intermediate-dose methotrexate or cranial irradiation as prophylactic therapy.

\section{Prophylactic (Intensified) Phase}

Intermediate-dose methotrexate was administered at a dosage of $500 \mathrm{mg}$ per square meter per day on three occasions at three-weck intervals. On each occasion one third of the dose was given as an intravenous bolus that would produce a serum level of methotrexate of $10^{-5} \mathrm{M}$, and then two thirds were infused over 24 hours to maintain this level for the period of the infusion. ${ }^{12}$ A single dose of leucovorin (12 mg per square meter) was administered 24 hours after completion of intermediate-dose methotrexatc administration. Intrathecal methotrexate ( $12 \mathrm{mg}$ per square meter; maximum single dose, $15 \mathrm{mg}$ ) was given concurrently with intermediate-dose methotrexate on three occasions. During intermediate-dose methotrexate administration, good hydration was mandatory (a minimum of 2000 $\mathrm{ml}$ per square meter per 24 hours). If severe mucosal ulceration occurred with intermediate-dose methotrexate, the next course was delayed until healing had occurred; the next course (or courses) was again given at full dosage, but an additional dose of leucovorin was administered 72 hours after the start of intermediate-dose methotrexatc.

Cranial irradiation was given over a period of 16 days in 200-rad increments, for a total of $2400 \mathrm{rad}$. External radiation was delivered to the whole brain, including the spinal cord down to C2. The radiation field included the entire frontal lobe and the posterior halves of the eyeballs, including the optic disks. The anterior halves of both eyes were shielded. The patients were treated with two lateral parallel opposed fields. Intrathecal methotrexate, $12 \mathrm{mg}$ per square meter (maximum single dose, $15 \mathrm{mg}$ ) weckly for three doses, was also administered during the period of cranial irradiation.

\section{Maintenance Phase}

Upon completion of the prophylactic phase, all patients received the same maintenance therapy, consisting of oral mercaptopurine (90 $\mathrm{mg}$ per square meter per day) plus oral methotrexate ( $15 \mathrm{mg}$ per square meter per week) on the first day of each weck. Reinforcement courses of vincristine and prednisone were given at Wecks 6, 12, 16, 20 , and 24 after the start of prophylactic therapy; starting at Week 28 , two weckly doses of vincristine plus two wecks of prednisone treatment were given, without tape:-ing of the doses, every 12 wecks for the duration of maintenance. During maintenance, vincristine and prednisone were given regardless of hematologic values; the 


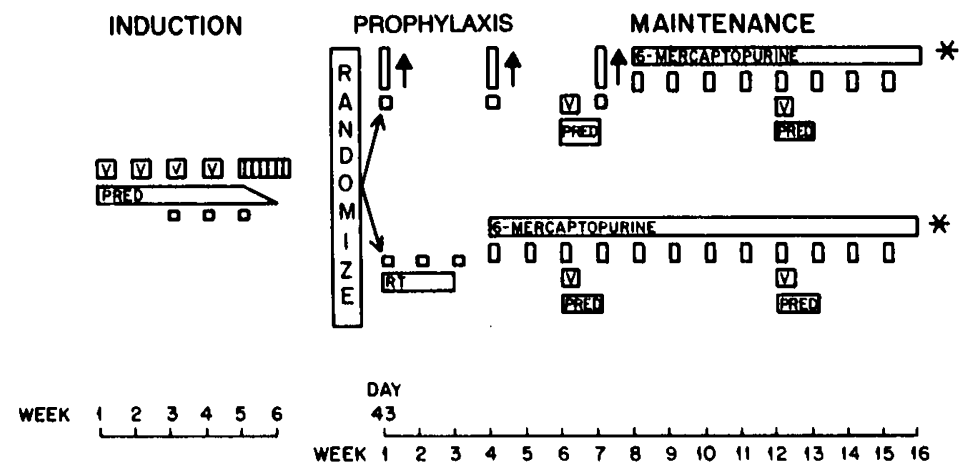

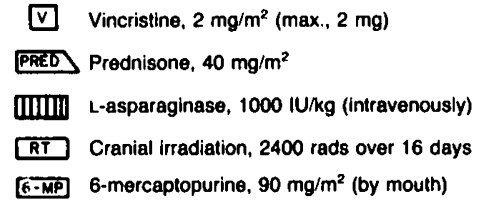

* Maintenance continued for three years

Figure 1. Treatment Phases of CALGB Protocol 7611 (Treatment of Primary Untreated Acute Lymphocytic Leukemia in Patients under 20 Years). doses of mercaptopurine and methotrexate were modified as follows: the entire dose was given if the white-cell count was above 2500 and the platelet count was above 100,000; half the dose was given if the white-cell count was 1500 to 2500 or the platelet count was 50,000 to 100,000 ; and none was given if the white-cell count was below 1500 or the platelet count was below 50,000.

After threc years of maintenance therapy, patients were completely recvaluated by means of biopsics of the bone marrow and testes and a diagnostic lumbar puncture, to determine their status with regard to remission.

\section{Results}

The study enrolled 634 patients from November 12, 1976, until July 16, 1979, when enrollment was closed. This preliminary analysis covered all available followup data through April 1981, for a median follow-up period of 40 months.

Of the 634 patients entered, 600 (95 per cent) were cvaluable for their response to induction therapy ('Table 1).

Complete remission was achieved in 548 of the 600 (91 per cent). As expected, the rate was higher among the standard-risk patients (251 of 262, 96 per cent) than among the increased-risk patients (297 of 338,88 per cent $)(\mathbf{P}<0.01)$.

Forty-two patients $(8 \mathrm{per}$ cent) with marrow indicating remission were not included in the analysis of the cffect of prophylactic therapy on remission duration (Table 2). Of the 506 cvaluable responders, 259 had been randomized to receive intermediate-dose methotrexate and 247 to receive cranial irradiation as prophylactic therapy ('Tablc 2).

The characteristics of the two treatment groups were very similar ('lable 3); the only possible exception was that twice as many children less than two years old belonged to the intermediate-dose methotrexatc arm $(P=0.09)$. Despite this, the effect of the prophylactic therapy on the duration of complete remission was similar: one third of these small subgroups in both treatment groups had relapses. Current remission status is summarized in Table 4, according to type of prophylactic treatment and risk stratum.

'The effect of treatment on overall, hematologic, and central-nervous-system remission among standardrisk patients is shown in Figures 2 through 4. Superior hematologic protection occurred after intermediatedose methotrexate therapy $(\mathrm{P}<0.01)$. In contrast, standard-risk patients had a higher rate of centralnervous-system relapse $(P=0.01)$ when treated with intermediate-dose methotrexate; the resultant overall continuous complete remission was similar in both treatment groups.

Among increased-risk patients there was no difference in the duration of complete remission (Fig. 5) or hematologic remission (Fig. 6) associated with prophylactic therapy. As in standard-risk patients, there was greater central-nervous-system protection in

Table 1. Patients Entered into Study or Disqualified (Induction Phase).

$\begin{array}{lr}\text { Number entered . . . . . . } & 6.34 \\ \text { Number disqualified . . . . } & 34 \\ \text { Ineligibility } & 10 \\ \text { Protocol violation } & 11 \\ \text { Early loss to study } & 3 \\ \text { Inadequate records } & 10 \\ \text { Number evaluable. ......600 }\end{array}$


Table 2. Patients Evaluable for Study (Prophylactic Phase).

\begin{tabular}{|c|}
\hline Number responding to induction therapy . . . . 548 \\
\hline Number not evaluable . . . . . . . . . \\
\hline Early relapse or loss to study \\
\hline Improper randomization (including refusals) \\
\hline Disqualification during maintenance therapy \\
\hline $\begin{array}{l}\text { Exclusion due to central-nervous-system } \\
\text { disease during induction therapy }\end{array}$ \\
\hline Inadequate records \\
\hline Number evaluable and randomized $\ldots \ldots \ldots .506$ \\
\hline Intermediate-dose methotrexate 259 \\
\hline Cranial irradiation \\
\hline
\end{tabular}

patients treated with cranial irradiation (Fig. 7) $(\mathrm{P}=0.03)$.

Interestingly, there were 11 occurrences of testicular relapsc in 269 male patients, 10 of them among patients receiving cranial irradiation $(P=0.01)$ (Tablc 4).

At cvaluation after three ycars of continuous completc remission with maintenance therapy, five rclapses were documented among 87 evaluable patients: one relapse in bone marrow, two in the testes, and two in the central nervous system.

Cox's regression model was used to assess simultancously the relative importance of various factors in remission duration. For standard-risk patients the possible prognostic variables considered were prophylactic therapy (intermediatc-dose methotrexate vs. crani-

Table 3. Comparability of Treatment Groups at Time of Diagnosis.

\begin{tabular}{|c|c|c|}
\hline & $\begin{array}{l}\text { INTHRMEDIATE- } \\
\text { DOSI: METHO- } \\
\text { TREXATE } \\
(n=259)\end{array}$ & $\begin{array}{l}\text { Cranial. } \\
\text { IRradi- } \\
\text { ATION } \\
(n=247)\end{array}$ \\
\hline $\begin{array}{l}\text { Risk of relapse ( } \% \text { of group) } \\
\text { Standard risk } \\
\text { Increased risk } \\
\text { Because of age } \\
\text { Because of white-cell count } \\
\text { Because of both factors }\end{array}$ & $\begin{array}{c}45 \\
55 \\
(32) \\
(12) \\
(11)\end{array}$ & $\begin{array}{l}49 \\
51 \\
(29) \\
(15) \\
(7)\end{array}$ \\
\hline $\begin{array}{l}\text { Age (\% of group) } \\
<2 \mathrm{yr} \\
2-7 \mathrm{yr} \\
8-19 \mathrm{yr}\end{array}$ & $\begin{array}{l}10 \\
57 \\
33\end{array}$ & $\begin{array}{r}5 \\
64 \\
31\end{array}$ \\
\hline $\begin{array}{l}\text { White-cell count (\% of group) } \\
\quad<30,000 / \mathrm{mm}^{3} \\
\geqslant 30,000 / \mathrm{mm}^{3}\end{array}$ & $\begin{array}{l}77 \\
23\end{array}$ & $\begin{array}{l}78 \\
22\end{array}$ \\
\hline Sex (M:F) & $50: 50$ & $57: 43$ \\
\hline $\begin{array}{l}\text { Per cent blasts in marrow } \\
\text { (group mean) }\end{array}$ & 86 & 85 \\
\hline Mean hemoglobin ( $\mathrm{g} / \mathrm{dl})$ & 7.9 & 7.9 \\
\hline $\begin{array}{l}\text { Mean platelet count } \\
\qquad\left(\times 10^{-3} / \mathrm{mm}^{3}\right)\end{array}$ & 81 & 75 \\
\hline $\begin{array}{l}\text { Per cent circulating blasts } \\
\text { (group mean) }\end{array}$ & 36 & 34 \\
\hline $\begin{array}{l}\text { Hepatomegaly }>4 \mathrm{~cm} \\
\text { (\% of group) }\end{array}$ & 32 & 38 \\
\hline $\begin{array}{l}\text { Splenomegaly }>4 \mathrm{~cm} \\
\text { (\% of group) }\end{array}$ & 29 & 31 \\
\hline $\begin{array}{l}\text { Nodal involvement } \\
\text { (\% of group) }\end{array}$ & 59 & 64 \\
\hline
\end{tabular}

al irradiation), initial white-cell count $(<10,000$ vs. 10,000 to 29,999 ), scx (male vs. female), and extent of organomegaly at diagnosis (extensive [ $>4-\mathrm{cm}$ hepatomegaly or splenomegaly, or extensive nodal involvement] vs. minimal). The multivariate regression analysis indicated that in standard-risk patients treatment with intermediate-dose methotrexate offered significantly grcater systemic protection $(P=0.002)$, whereas cranial irradiation offered greater protection against central-nervous-system disease $(P=0.007)$. Overall, the presence of extensive organomegaly at diagnosis significantly diminished the duration of complete remission in standard-risk patients $(P=0.039)$. Among increased-risk patients the variables considered were prophylactic therapy, risk classification (increased risk due to age alone, white-cell count alone, or both features), sex, and extent of organomegaly at diagnosis. This analysis indicated that the feature for which a

Table 4. Remission Status at Last Evaluation (April 1981).

\begin{tabular}{|c|c|c|c|c|}
\hline \multirow[t]{2}{*}{$\begin{array}{l}\text { Remission } \\
\text { Status }\end{array}$} & \multicolumn{2}{|c|}{$\begin{array}{l}\text { INTERMI:DIATE:-DOSE: } \\
\text { MEIHOIRE:XAII: }\end{array}$} & \multicolumn{2}{|c|}{$\begin{array}{c}\text { Cranial. } \\
\text { IrRabiation }\end{array}$} \\
\hline & $\begin{array}{l}\text { STANDARD } \\
\text { RISK } \\
(\mathrm{n}=117)\end{array}$ & $\begin{array}{l}\text { INCRL:ASI:D } \\
\text { RISK } \\
(n=142)\end{array}$ & $\begin{array}{c}\text { STANDARD } \\
\text { RISK } \\
(n=120)\end{array}$ & $\begin{array}{c}\text { INCRLASED } \\
\text { RISK } \\
(n=127)\end{array}$ \\
\hline & \multicolumn{4}{|c|}{ number of patients } \\
\hline In complete remission & 79 & 70 & 77 & 68 \\
\hline \multicolumn{5}{|l|}{ Relapse } \\
\hline Marrow & 9 & 35 & 24 & 38 \\
\hline CNS * & 18 & 14 & 6 & 1 \\
\hline $\begin{array}{l}\text { Simultaneous marrow } \\
\text { and CNS }\end{array}$ & 0 & 6 & 1 & 6 \\
\hline CNS followed by marrow & 5 & 10 & 1 & 3 \\
\hline $\begin{array}{l}\text { Testicular (no. affected/ } \\
\text { no. male) }\end{array}$ & $0 / 56$ & $1 / 73+$ & $3 / 67$ & $7 / 73 \ddagger$ \\
\hline $\begin{array}{l}\text { Death during complete } \\
\text { remission }\end{array}$ & 3 & 0 & 1 & 1 \\
\hline Lost to study & 3 & 6 & 7 & 3 \\
\hline
\end{tabular}

*Central nervous system.

this patient also had simultancous bone-murrow and central-nervous-system relapses. $¥$ Two of these patients also had simultaneous bone-marrow relapse

paticnt was classified as being at increased risk had a significant impact on predicting the duration of hematologic remission $(P=0.001)$, favoring those at increased risk due to age alone. This model showed that central-ncrvous-systcm remission was significantly prolonged in patients who reccived cranial irradiation $(P=0.001)$ and who had minimal or no organomegaly at diagnosis $(P=0.005)$. Overall, of the factors considered in this analysis, increased risk duc to age alone had the least negative impact on the duration of complctc remission.

CALGB classified patients as being at standard risk if they were two to seven years old with a white-cell count below 30,000 per cubic millimeter at presentation. When duration of complete remission was analyzed according to risk classification, an increased risk duc to initial whitc-cell count - without any restriction on age - conferred a poorer prognosis within cach treatment group (intermediate-dose methotrexatc, $\mathrm{P}<0.001$; cranial irradiation, $\mathrm{P}=0.002)$. Re- 
sponders at increased risk because of age alone represented a group at an intermediate risk with respect to prolonging of complete remission. When the duration of complete remission was evaluated according to age alone, an age of 8 to 10 years at diagnosis did not carry a poorer prognosis than an age of 2 to 7 ; of the 60 patients in the older age group, 51 (85 per cent) were classified as being at increased risk because of age alone.

Overall, intermediate-dose methotrexate was quite tolerable: 94 per cent of the patients received the full three doses ('Table 5). Overt clinical leukoencephalopathy was not observed with intermediate-dose methotrexate in this study. Mucositis (generally mild) was the most common problem. Furthermore, the vast majority of patients received the prescribed amount of intermediate-dose methotrexate. In 95 per cent of the cases cranial irradiation was administered at the recommended dosage; compliance with the protocol for

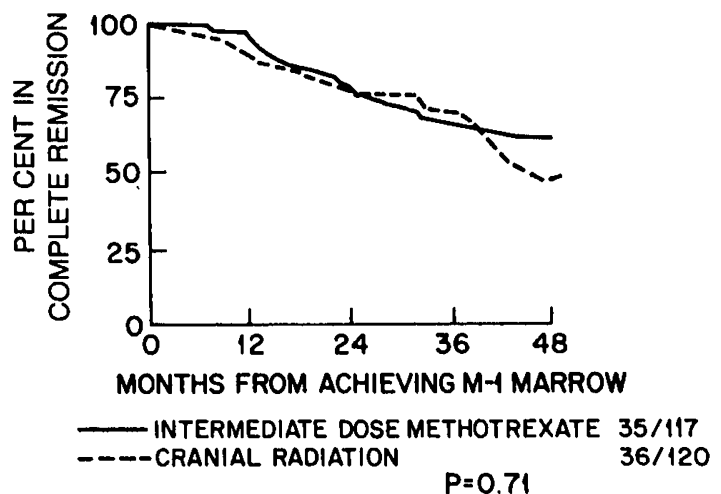

Figure 2. Duration of Complete Remission (Shown by M-1 Marrow) in Standard-Risk Patients.

The proportions at the bottom of the figure represent the numbers of patients who had a relapse.

cranial irradiation was evaluated by the C:AI,GB Radiotherapy Quality Assurance Committec to determine the effects of dosing and field accuracy on central-nervous-system remission.

Methotrexate levels were determined only at selected institutions; serum levels reached $10^{-5} \mathrm{M}$ during the period of administration, and simultancously determined cercbrospinal-fluid levels were $10^{-7} \mathrm{M}$. These findings have been published previously. ${ }^{13}$

\section{Discussion}

This study (CALGB 7611) was a straightforward comparison between intermediate-dose methotrexate given on three occasions plus intrathecal methotrexate, and cranial irradiation (2400 rad) plus intrathecal methotrexate, in patients who had a complete remission. These two treatments were added to what was considered the best standard induction and maintenance treatment when the study was designed. Vincristine and prednisone were used in a standard induction regimen followed by a 10-day program of

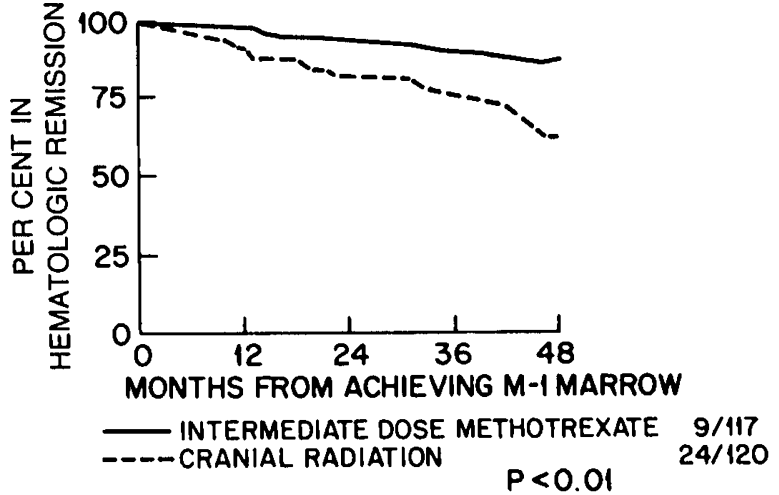

Figure 3. Duration of Hematologic Remission in Standard-Risk Patients.

asparaginase. The asparaginase was used in this fashion because of the findings of Jones et al., which demonstrated an improved duration of complete remission in patients with $\Lambda \mathrm{I} \mathrm{L}$, when asparaginase treatment followed vincristine-prednisone induction therapy. ${ }^{22}$ Maintenance therapy consisted of daily mercaptopurine and weekly methotrexate, plus reinduction with pulsed doses of prednisone and vincristine.

The clinical basis for testing intermediate-dose methotrexate was the carly work of Djerassi, who demonstrated the effectiveness of high doses of methotrexate in $\Lambda \mathrm{L} \mathrm{L}^{23}$; CALGB Protocol 6601, which showed that the proportion of children remaining in complete remission wats highest among those who received intensive cycles of intravenous methotrexate $18 \mathrm{mg}$ per square meter daily for five days every two weeks (i.e., a total dose of $90 \mathrm{mg}$ per square meter every two wecks), with reinduction pulses of vincristine and prednisone repeated over a period of nine months ${ }^{1}$; and the pilot study of intermediate-dose methotrexate conducted at the Roswell Park Memorial Institute, which indicated, in a nonrandomized fashion, its effectiveness as therapy for ALI, particu-

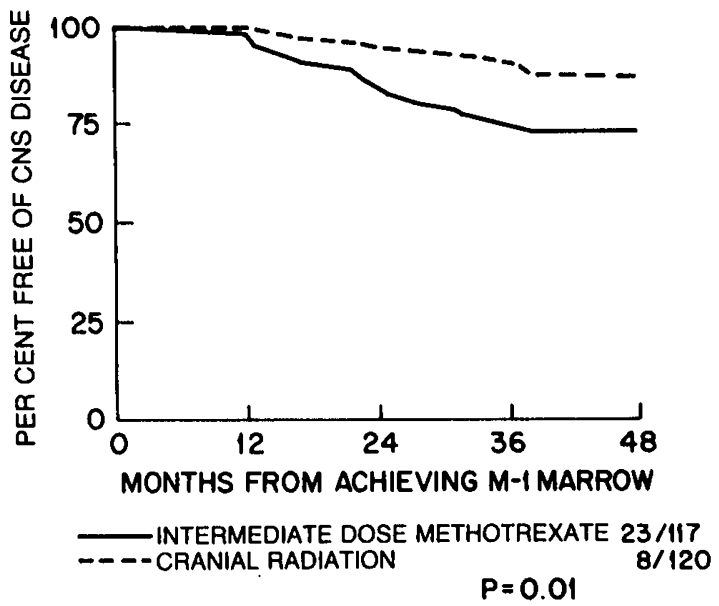

Figure 4. Duration of Central-Nervous-System (CNS) Remission in Standard-Risk Patients. 


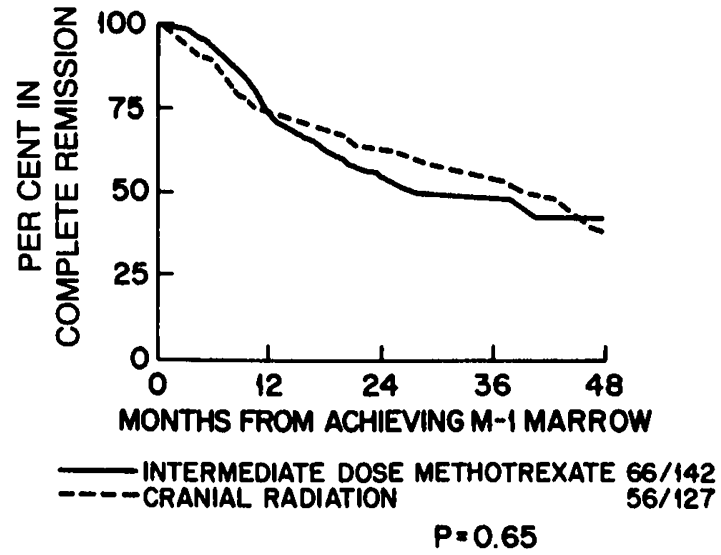

Figure 5. Complete Remission in Increased-Risk Patients.

larly among standard-risk patients. ${ }^{24} \mathrm{~A}$ very similar study, evaluated by Moe and Scip, also had very promising results. ${ }^{25}$

The pharmacologic basis of this study included the following: (1) reports showing that intravenous intermediate-dose methotrexate resulted in methotrexate levels of $10^{-7} \mathrm{M}$ that reached the central-nervoussystem axis and diffused into the cerebrospinal fluid $^{13,26}$; (2) the studies of Oldendorf and Davson, using $\left[{ }^{14} \mathrm{C}\right]$ sucrose in rabbits, ${ }^{27}$ and of Bourke et al., using $\left[{ }^{14} \mathrm{C}\right]$ fluorouracil in monkeys,${ }^{28}$ which demonstrated that the concomitant use of intrathecal and intravenous injection led to higher levels of drug in the cercbrospinal fluid and a more even distribution throughout the central nervous system than the use of either method alone; and (3) the finding that when methotrexate was given only by lumbar puncture the distribution of the drug throughout the cerebrospinal fluid varied greatly. ${ }^{25}$ Studies in human beings have corroborated these observations in animals - i.c., that higher cerebrospinal-fluid levels of methotrexate are present for longer periods when the drug is administered by concomitant intrathecal and intravenous injection rather than by cither technique alonc. ${ }^{29}$ Thus, the technique used in the present study of simultaneous intermediate-dose methotrexate plus intrathe-

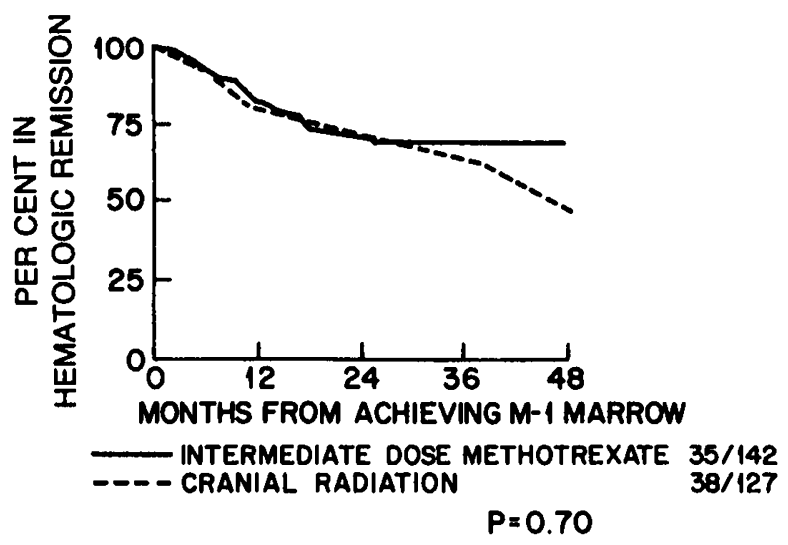

Figure 6. Hematologic Remission in Increased-Risk Patients. cal methotrexate enabled the physician to bathe the entire central-nervous-system axis more effectively. After a dose of $500 \mathrm{mg}$ per square meter the scrum methotrexate levels remained at $10^{-5} \mathrm{M}$ for the 24-hour infusion period. ${ }^{13}$ It was also anticipated that intermediate-dose methotrexate would afford protection to other "sanctuary" sites, such as the gonads, liver, and splcen. Recently, Riccardi et al. have shown in rats that the gradient between methotrexate in serum and methotrexate in the interstitial tissuc of the testes was 4:1, suggesting that higher doses are more cffective in cradicating leukemic cells in the testes. ${ }^{30}$

An alternative treatment to cranial irradiation has become particularly important, since recent evidence has indicated that cranial irradiation is toxic to the brain. In a study by Moss et al. children with ALL treated with cranial irradiation plus multiple doses of intrathecal chemotherapy had a significant mcan drop in IQ of approximatcly 12 points, as comparcd with their siblings. ${ }^{12}$ Brecher et al. compared 106 children

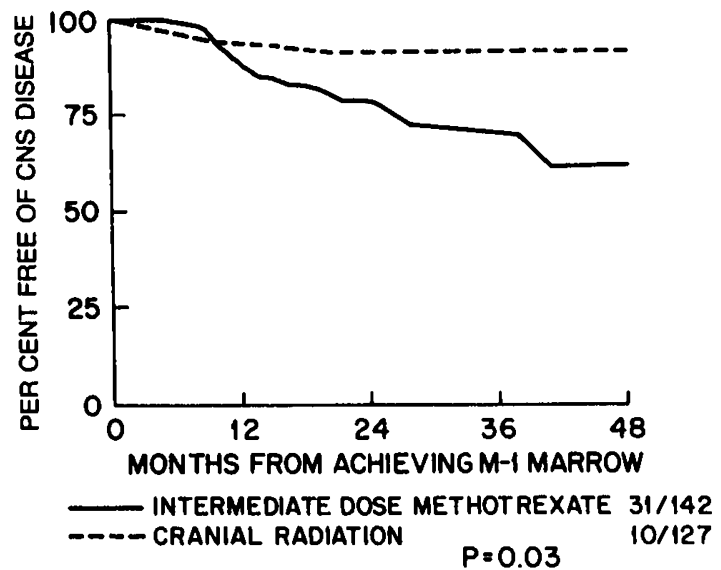

Figure 7. Central-Nervous-System Remission in Increased-Risk Patients.

entered in three CALGB studies who had been randomized to receive intrathecal methotrexate alone, intrathecal methotrexate plus cranial irradiation, or intrathecal methotrexate plus intermediate-dose methotrexate. ${ }^{31}$ The children who received cranial irradiation had significantly lower performance and verbal IQs than those not given irradiation. The mean drop in IQ was again approximatcly 12 points. ${ }^{31,32}$ There were no differences between the patients who received intermediate-dose methotrexate plus intrathecal methotrexate and those who received intrathecal methotrexate alone.

It should be pointed out that there are risks to the use of intermediate-dose methotrexate alone. Cohen et al. have reported an increased incidence of electrocncephalographic abnormalities in patients given this type of dosage, although these abnormalities have so far not been accompanied by an increased incidence of convulsions. ${ }^{33}$ The potential late deleterious effect of both intermediate-dose methotrexate and cranial irra- 
diation is under careful investigation in an ongoing longitudinal study of psychometric, cognitive, ncurologic, and endocrine functions in long-term survivors treated according to CALGB protocols.

In this study, although continuous completc remission was the same among standard-risk and increasedrisk patients receiving cither intermediate-dose methotrexate or cranial irradiation, the pattern of relapse was different. Standard-risk patients recciving intermediate-dose methotrexate had significantly fewer bonc-marrow relapses $(\mathrm{P}<0.01)$ but significantly more central-ncrvous-system relapses $(P=0.01)$. Increased-risk patients recciving cranial irradiation also had significantly fewer central-nervous-system relapses $(P=0.03)$. Also noteworthy was the significantly lower number of testicular relapses in malc patients receiving intermediate-dose methotrexate $(P=0.01)$. The difference in the pattern of relapse is important, because the salvage rate among children with an isolated central-ncrvous-system relapse has becn shown to be significant ${ }^{34,35}$ Indecd, to datc the Children's Cancer Study Group has not found any negative effect on survival related to an isolated central-ncrvous-system relapse. ${ }^{2}$ Furthermore, Bowman et al. have observed that an isolated testicular relapse during maintenance therapy is followed by systemic relapse in a median period of three months, thereby indicating a poor prognosis; in contrast, patients with an isolated testicular relapse after cessation of therapy have a significant salvage ratc. ${ }^{36}$ Morcover, apart from children given bonc-marrow transplants, ${ }^{37}$ virtually no children who have a bonc-marrow relapse whilc recciving chemotherapy are cured. Thus, an isolated central-nervous-system relapse during therapy docs not carry as grave a prognosis as docs a bonc-marrow rclapse $^{2}$ or a testicular rclapse. ${ }^{36}$

Three courses of intermediate-dose methotrexate, along with only six doses of intrathecal methotrexate, appear to be insufficient prophylaxis for the central nervous system of patients with ALL. Van Eys, ${ }^{38}$ Komp,${ }^{39}$ and Sullivan ${ }^{40}$ and their collcagues, reporting on the experience of the Southwest Oncology Group, have shown that among patients with ALL (except for those with T-cell ALL) who were at standard or increased risk, there was no difference between patients receiving cranial irradiation plus intrathecal chemotherapy and those receiving multiple repetitive intrathecal chemotherapy for up to threc years, in terms of central-ncrvous-system protection or the duration of complete remission. In both groups the incidence of central-nervous-system relapse as the first site of treatment failure was less than 10 per cent. An alternative approach was that of the Children's Cancer Study Group, which has demonstrated that $1800 \mathrm{rad}$ was as effective as 2400 rad in providing central-nervous-system protection in children with ALL. ${ }^{41}$

A pilot study conducted at the Roswell Park Memorial Institute has shown that increased-risk patients receiving six courses of intermediatc-dose methotrexatc had a significantly longer duration of complete
Table 5. Toxic Complications of Intermediate-Dose Methotrexate.

\begin{tabular}{lcc}
\hline \hline Compl.ICATION & \multicolumn{2}{c}{ Toxicitr } \\
& $\begin{array}{c}\text { MIL.D to } \\
\text { MODERATE }\end{array}$ & SEVERE \\
& \multicolumn{2}{c}{ no. of patients (per cent *) } \\
Mucositis & $68(38)$ & $6(3)$ \\
Hematologic & $25(15)$ & 0 \\
Hepatic & $19(11)$ & $1(1)$ \\
Gastrointestinal & $18(11)$ & 0 \\
Infection & $13(8)$ & $1(1)$
\end{tabular}

Definitions $\uparrow$

$\begin{array}{ll}\begin{array}{l}\text { Mucositis } \\ \text { Mild } \\ \text { Moderate } \\ \text { Severe }\end{array} & \begin{array}{l}\text { Oral erythema or pain } \\ \text { Ulcers but ability to eat } \\ \text { Inability to eat, drooling, or both, } \\ \text { secondary to ulcers } \\ \text { White cells }<1.0 / \mathrm{mm}^{3}\end{array} \\ \text { Hematologic - severe } & \begin{array}{l}\text { Neutrophils }<500 / \mathrm{mm}^{3} \\ \text { Platelets }<50,000 / \mathrm{mm}^{3}\end{array} \\ \text { Hepatic - mild to } & \begin{array}{l}\text { Up to three time the upper normal } \\ \text { level of enzymes } \\ \text { moderate }\end{array} \\ \text { Occasional abdominal pain, nausea and } \\ \text { vomiting, and diarthea } \\ \text { Infection - severe } & \begin{array}{l}\text { Temperature } \geqslant 38^{\circ} \mathrm{C} \text {, systemic signs of } \\ \text { infection, severe local infection, or } \\ \text { visceral sepsis - i.e., life-threatening }\end{array}\end{array}$

*Percentage of paticnts in whom toxicity data were adequately neponed.

tDerived from CAL.GB criteria.

remission, which was attributed to the occurrence of fewer systemic relapses, as compared with patients receiving only threc courses of intermediate-dose methotrexatc. ${ }^{42}$ Morcover, the West Berlin Study Group has reported that very intensive therapy given soon after remission improves the prognosis among increased-risk patients with ALL. ${ }^{43}$

Thus, it appears that in a substantial proportion of patients, intensive repetitive intrathecal chemotherapy, along with repetitive intcrmediate-dose methotrexate and carly intensive therapy, could result in an improved rate of complete remission and probably prevent the potential ncurotoxicity of cranial irradiation. Such a study is being conducted by the Pediatric Oncology Group. Prophylactic cranial irradiation can probably be avoided in standard-risk patients with ALL and in a proportion of increased-risk patients. Nonetheless, at present it is likely that some increasedrisk patients will still require cranial irradiation; these may include patients presenting with T-cell ALL or pre-B-cell ALL, who have a higher incidence of extramedullary relapsc, or those presenting with a very high white-cell count. ${ }^{38,39}$ Perhaps the dose of cranial irradiation in this group could be decreased to $1800 \mathrm{rad}$, which might decrease the toxicity to the central nervous system. Indeed, in these increased-risk subgroups it appears reasonable to test delaying cranial irradiation and first administering intensive therapy including intermediate-dose methotrexate plus intrathecal chemotherapy. This approach might prevent the additive toxicity of cranial irradiation and systemic methotrexate, since it has been suggested that cranial irradiation alters the blood-brain barrier, paving the way for methotrexate-induced central-nervous-system 
lcukoencephalopathy. ${ }^{15}$ By reversing this order of events, one might avoid toxicity and still retain the additive benefit of both modalities.

In our study the toxicity of intermediate-dose methotrexate was within acceptable limits. Neither a drop in IQ nor leukoencephalopathy was noted, and bonemarrow depression was mild, but an increased number of electroencephalographic abnormalitics was observed. Oral ulcerations were the most troublesome problcm.

In conclusion, although there was no difference in continuous completc remission in association with prophylactic therapy within the confines of this study, intermediate-dose methotrexate conferred greater protection to the bone marrow in standard-risk patients and to the testes in male patients, whereas cranial irradiation conferred greater protection to the central nervous system. However, the use of intermediatedose methotrexate probably avoids the long-term toxicity to the central nervous system that is inherent in cranial irradiation. Furthermore, intensifying intrathecal chemotherapy may replace the need for cranial irradiation in many children with AI.L.

\section{REFERENCES}

1. Evans AE, Gilbert ES, Zandstra $\mathrm{A}$. The increasing incidence of central nervous system leukemia in children (Children's Cancer Study Group A). Cancer. 1970; 26:404-9.

2. Nesbit ME, D'Angio GJ, Sather HN, et al. Effect of isolated central nervous system leukaemia on bone marrow remission and survival in childhood acute lymphoblastic leukaemia: a report for Children's Cancer Study Group. Lancet. 1981; 1:1386-9.

3. Simone JV. Leukacmia remission and survival. Lancet. 1981; 2:531.

4. Holland JF, Glidewell $O$. Oncologists' reply: survival expectancy in acute lymphocytic leukemia. N Engl J Med. 1972; 287:769-77.

5. Aur RJA. Simone JV, Hustu HO), et al. Central nervous system therapy and combination chemotherapy of childhood lymphocytic leukemia. Blood. 1971: 37:272-81.

6. Aur RJA, Simone JV, Hustu HO, Verzosa MS. A comparative study of central nervous system irradiation and intensive chemotherapy early in remission of childhood acute lymphocytic leukemia. Cancer. 1972; 29:38191.

7. Aur RJA, Hustu HO, Verzosa MS, Wood A. Simone JV. Comparison of two inethods of preventing eentral nervous system leukemia. Blood. 1973; 42:349-57.

8. Hustu HO, Aur RJA, Verzosa MS, Simone JV, Pinkel D. Prevention of central nervous system leukemia by irradiation. Cancer. 1973; 32:585-97.

9. Pinkel D, Hustu HO, Aur RJA, Simith K, Borella LD, Simone J. Radiotherapy in leukemia and lymphoma of children. Cancer. 1977; 39:817-24.

10. Land VJ, Berry DH, Herson J, et al. Long-tern survival in childhood acute leukemia: "late" relapses. Med Pediatr Oncol. 1979; 7:19-24.

11. Baum E, Sather H, Nachman J, et al. Relapse rates following cessation of chemotherapy during complete remission of acute lymphocytic leukemia. Med Pediatr Oncol. 1979; 7:25-34.

12. Moss HA, Nannis ED, Poplack DG. The effects of prophylactic treatment of the central nervous system on the intellectual functioning of children with acute lymphocytic leukemia. Am J Med. 1981; 71:47-52.

13. Wang JJ, Freeman Al, Sinks LF. Treatment of acute lymphocytic leukemia by high-dose intravenous methotrexate. Cancer Res. 1976; 36:1441-4.

14. Ellison RR, Holland JF, Weil M, et al. Arabinosyl cytosine: a useful agent in the treatment of acute leukemia in adults. Blocol. 1968; 32:507-23.

15. Peylan-Ramu N, Poplack DG. Pizzo PA. Adornato BT, Di Chiro G. Abnormal CT scans of the brain in asymptomatic children with acute lymphocytic leukemia after prophylactic treatment of the central nervous system with radiation and intrathecal chemotherapy. N Engl J Med. 1978; 298:815. 8.

16. Kay HEM, Knapton PJ, O'Sullivan JP, et al. Encephalopathy in acute leukaemia associated with methotrexate therapy. Arch Dis Child. 1972: 47:344-54.
17. Price $R \Lambda$, Jamieson $P \Lambda$. The central nervous system in childhood leukemia. II. Subacute leukoencephalopathy. Cancer. 1975: 35:306-18.

18. Cutler SJ, Ederer F. Maximum utilization of the life table method in analyzing survival. J Chronic Dis. 1958; 8:699-712.

19. Breslow N. $\wedge$ generalized Kruskal-Wallis test for comparing $K$ samples subject to unequal patterns of censorship. Biometrika. 1970; 57:579-94.

20. Snedecor GW. Cochran WG. Statistical methods. 6th ed. Ames, Iowa: lowa State University Press, 1967:228.

21. Cox DR. Regression models and life-tables. J R Stat Soc [B]. 1972; 34:187220 .

22. Jones B, Holland JF. Glidewell $O$, et al. Optimal use of L-asparaginase (NSC-109229) in acute lymphocytic leukemia. Med Pediatr Oncol. 1977; 3:387-400.

23. Djerassi I, Farber S, Abir E, Neikirk W. Continuous infusion of methotrexate in children with acute leukemia. Cancer. 1967; 20:233-42.

24. Sinks LF, Wang JJ, Freeman AI. The treatment of primary childhood acute lymphocytic leukemia with internediate dose methotrexate. In: Neth $R$. Gallo RC, Graf T, Mannweiler K, Winkler K, eds. Modern trends in human leukemia IV. Berlin: Springer-Verlag, 1981:99-107.

25. Moe PJ, Scip M. High dose methotrexate in acute lymphocytic leukemia in childhood. Acta Paediatr Scand. 1978; 67:265-8.

26. Shapiro WR, Young DF, Mehta BM. Methotrexate: distribution in cerebrospinal fluid after intravenous, ventricular and lumbar injections. N Engl J Med. 1975; 293:161-6.

27. Oldendorf WH, Davson J. Brain extracellular space and the sink action of cerebrospinal fluid: measurement of rabbit brain extracellular space using sucrose labeled with carbon 14. Arch Neurol. 1967; 17:196-205.

28. Bourke RS, West CR. Chheda G. Tower DB. Kinetics of entry and distribution of 5-fluorouracil in cerebrospinal fluid and brain following intravenous injection in a primate. Cancer Res. 1973; 33:1735-46.

29. Freeman AI, Wang JJ, Sinks LF. High-dose methotrexate in acute lymphocytic leukemia. Cancer Treat Rep. 1977; 61:727-31.

30. Riccardi R, Vigersky RA, Barnes S, Bleyer WA, Poplack DG. Methotrexate levels in the interstitial space and seminiferous tubule of rat testis. Cancer Res. 1981; 42:1617-9.

31. Brecher ML, Freeman AI, Glicksman AS, et al. Long term toxicity of central nervous system prophylaxis in acute lymphocytic leukemia (for Cancer and Leukemia Group B). In: Freeman A. Pochedly C. eds. Controversies in pediatric oncology. Paris: Masson. (in press).

32. Rowland J, Glidewell O. Sibley JR, et al. Effect of cranial radiation (CRT) on neuropsychologic function in children with acute lymphocytic leukemia (ALL). Proc Am Soc Clin Oncol. 1982; 1:123. abstract.

33. Cohen ME, Duffner PK, Brecher ML, Diamond LS, Glicksman AS. Freeman AI. EEGs in disease-free children with acute lymphocytic leukemia. Proc Am Soc Clin Oncol. 1982; 1:135. abstract.

34. Frankel LS, Hockenberry MJ, Johnston DA. The curative potential of central nervous system (CNS) relapse in childhood acute lymphocytic leukemia (ALL). Proc Am Soc Clin Oncol. 1982; 1:124. abstract.

35. Wells RJ, Weetman RM, Baehner RL. The impact of isolated central nervous system relapse following initial complete remission in childhood acute lymphocytic leukemia. J Pediatr. 1980; 97:429-32.

36. Bowman WP, Aur RJ, Hustu HO, Rivera G. Survival following testicular relapse in acute lymphocytic leukemia (ALL): the influence of initial remission duration. Proc Am Soc Clin Oncol. 1982: 1:127, abstract.

37. Thomas ED, Storb R. Clift RA, ct al. Bone-marrow transplantation. N Engl J Med. 1975; 292:832-43, 895-902.

38. van Eys J. Shuster J. Boyett J, et al. Central nervous system leukemia prevention with intrathecal therapy alone. In: Freeman $\Lambda$, Pochedly C, eds. Controversics in pediatric oncology. Paris: Masson. (in press)

39. Komp DM, Fernandez CH. Falletta JM, et al. CNS prophylaxis in acute lymphoblastic leukemia: comparison of two methods: a Southwest Oncology Group Study. Cancer. 1982: 50:1031-6.

40. Sullivan MP. Chen T, Dyment PG, Hvizdala E, Steuber CP. Equivalence of intrathecal chemotherapy and radiotherapy as central nervous system prophylaxis in children with acute lymphatic leukemia: a Pediatric Oncology Group Study. Blood. 1982; 60:948-58.

41. Nesbit ME Jr, Sather HN, Robison LL, et al. Presymptomatic central nervous system therapy in previously untreated childhood acute lymphoblastic leukatemia: comparison of 1800 rad and 2400 rad: a report for Children's Cancer Study Group. Lancet. 1981; 1:461-6.

42. Green DM. Brecher ML, Blumenson LE, Grossi M. Freeman Al. The use of intermediate dose methotrexate in increased risk childhood acute lymphoblastic leukemia: a comparison of three versus six courses. Cancer. 1982; 50:2722-7.

43. Henze G, Langermann HJ, Ritter J, Schellong G, Richm H. Treatment strategy for different risk groups in childhood acute lymphoblastic leukemia: a report from the BFM Group. In: Neth R. Gallo RC, Graf T, Mannweiler K, Winkler K. eds. Modern trends in human leukemia IV. Berlin: SpringerVerlag, 1981:87-98. 